
КОНЦЕПТУАЛІЗАЦІЇ СОЦІОЛОГІЧНОЇ СКЛАДОВОЇ ОСВІТНЬОЇ ПРОГРАМИ

Сорока Юлія Георгіївна - доктор соціологічних наук, доцент, професор кафедри - соціології та кафедри соціології управління та соціальної роботи Харківського національного - університету імені В. Н. Каразіна, майдан Свободи, 4, Харків, 61022, Україна, email: Yuliya.soroka@karazin.ua, ORCID ID http://orcid.org/0000-0002-4158-1636.

Борисов Роман Ігорович - кандидат соціологічних наук, старший викладач кафедри - соціології Харківського національного університету імені В. Н. Каразіна, майдан Свободи, 4, - Харків, 61022, Україна, email: r.i.borysov@karazin.ua, ORCID ID https://orcid.org/0000-0003- $\underline{3757-3630 .}$.

У статті пропонується розгляд та обтрунтування концептуальних засад вивчення соиіології в рамках освітньої програми «Соціальна робота» на соиіологічному факультеті - Харківського національного університету імені В. Н. Каразіна. Актуальність такої - постановки завдання пов'язана з обговоренням мети иієї освітньої програми та їі - особливостей, які полягають, зокрема, в поглибленій підготовиі з соціології. На основі - характеристик та особливостей освітньої програми в статті сформульовані важливі положення, щзо спрямовують концептуалізацію ї̈ сочіологічної складової, зокрема характер дисцииліни, головне спрямування сочіологічної складової підготовки, ї̈ иентральний концепт - та вимоги до структури. Визначені тематичні пріоритети у викладанні курсів з сочіологї - та історії сочіології в рамках освітньої програми «Соціальна робота».

- Представлене обтрунтування концептуальних засад та тематичної структури курсу - «Історія сочіологї̈. Зокрема, визначені головні питання, на які має відповісти курс $i$ - відповідно до яких був підібраний історико-соиіологічний матеріал. Обгрунтована - переорієнтація з методологічних на онтологічні особливості сочіологічного теоретизування. - Обраний засіб парадигмального об'єднання соиіологічних концепцій задля ефективного - розуміння студентами сутності сочіологічного мислення. Схарактеризовані головні розділи - курсу та представлена його тематична структура.

Запропонований тематичний план курсу «Соціологія» як елементу соиіологічної складової освітньої програми «Соціальна робота» та аргументовані його відмінності від тематичної структури курсу «Соціологія» для непрофільних аудиторій. За допомогою - звернення до психолого-педагогічних та дидактичних аспектів схарактеризовано - запровадження відповідної системи методів викладання, навчання, підтримки та - оцінювання навчальної діяльності в рамках курсів «Соціологія» та «Історія сочіології».

Ключові слова: соціальна робота, освітня програма, соціологічна складова, соціологія, історія социології.

(C) Сорока Ю. Г., Борисов Р. І., 2021 


\section{«SOCIOLOGY» AND «HISTORY OF SOCIOLOGY» FOR «SOCIAL WORK»: TO THE CONCEPTUALIZATION OF SOCIOLOGICAL COMPONENT EDUCATION}

Soroka Yuliya - Doctor of Science (Sociology), Associate Professor, Professor of Department of Sociology and Department of Sociology of Management and Social Work, V. N. Karazin Kharkiv National University, 4, Svobody Sq., Kharkiv, 61022, Ukraine, email: Yuliya.soroka@karazin.ua, ORCID ID http://orcid.org/0000-0002-4158-1636.

Borisov Roman - PhD in Sociological Science, Senior Lecture of Sociology Department, V. N. Karazin Kharkiv National University, 4, Svobody Sq., Kharkiv, 61022, Ukraine, email: r.i.borysov@karazin.ua, ORCID ID https://orcid.org/0000-0003-3757-3630.

The article proposes a review and substantiation of the conceptual foundations of the study of sociology within the framework of the Educational Programme «Social work» at the sociological faculty of V. N. Karazin Kharkiv National University. The relevance of such a statement of the problem is associated with a discussion of the definition of the purpose of this educational program and its features, which consist, in particular, in in-depth training in sociology. Based on the characteristics and features of the educational program, the article formulates the initial provisions that guide the conceptualization of its sociological component, in particular, the nature of the discipline, the main direction of the sociological component of training, its central concept and requirements for the structure. Thematic priorities in teaching courses in "Sociology» and «History of Sociology" within the framework of the Social Work educational program have been determined.

The substantiation of the conceptual foundations and thematic structure of the course "History of Sociology» is presented. In particular, the main questions have been identified that the course should answer and, accordingly, the historical and sociological material was selected. Reorientation from methodological to ontological features of sociological theorizing is substantiated. A method of paradigmatic unification of sociological concepts for effective understanding by students of the essence of sociological thinking has been chosen. The main sections of the course are characterized and its thematic structure is presented.

The thematic plan of the course "Sociology» as an element of the sociological component of the educational program "Social work» is proposed and its differences from the thematic structure of the sociology course for non-core audiences are argued. By referring to the psychological, pedagogical and didactic aspects, the author describes the introduction of an appropriate system of methods of teaching, learning, support and assessment of educational activities within the framework of the courses «Sociology» and «History of Sociology».

Key words: social work, educational programme, sociological component, sociology, history of sociology.

Викладання соціальної роботи має багаторічну традицію на соціологічному факультеті Харківського національного університету імені В. Н. Каразіна $[1,2,3,4]$. Безпосередньо зараз, в перспективі оцінки якості освітньо-професійної програми (ОПП), актуалізована можливість концептуалізувати соціологічну складову цієї освітньої програми, зокрема місце, роль та зміст таких дисциплін, як «Соціологія» та «Історія соціології». 
Мета ОПП ${ }^{1}$ «Соціальна робота» формулюється наступним чином: «Підготовка фахівців, здатних до вирішення прикладних завдань соціальної сфери, у тому числі управління соціальними процесами та процесами, що мають місце в індивідуальному розвитку особистості, яка базується на сучасних міждисциплінарних знаннях із соціальної роботи з поглибленим вивченням соціології та соціального управління».

Остання фраза розкривається у визначенні особливості освітньої програми: «Програма базується на сучасних міждисциплінарних наукових знаннях у галузі соціальної роботи та пропонує поглиблену підготовку з соціології та соціального управління, що є важливим для вирішення прикладних професійних завдань. Соціологічна підготовка дозволяє майбутнім соціальним працівникам опанувати комплексним підходом до розуміння суспільства та його складових, а також застосовувати соціологічне знання та методи у вирішенні проблем соціальної сфери. Підготовка 3 соціального управління дозволяє майбутнім соціальним працівникам розуміти особливості організації діяльності щодо вирішення соціальних проблем в суспільстві та набути необхідних компетенцій щодо їі здійснення»². Зазначені особливості є необхідним аспектом якості освітньої програми та демонструють специфіку підходу до підготовки фахівців 3 соціальної роботи, яка вирізняється доволі широким розмаїттям $[5,6,7]$.

3 перелічених вище рис особливостей освітньої програми походять наступні важливі положення, що спрямовують концептуалізацію соціологічної складової освітньої програми. A саме:

- снання з соціальної роботи мають міждисциплінарний характер;

- $\quad$ підготовка 3 соціології спрямована на застосування знань та навичок у вирішенні прикладних професійних завдань;

- центральним концептом для побудови соціологічної складової навчального процесу та таким, що поєднує всі три змістовних складових навчального процесу (соціальна робота, соціологія, соціальне управління) є проблеми соціальної сфери;

- структура соціологічної підготовки включає знання з соціологічної теорії (різних рівнів та змістовних напрямків) та методів соціологічних досліджень.

Виходячи з цих положень, завданнями для соціологічної складової навчального процесу, зокрема дисциплін «Соціологія» та «Історія соціології», є формування знань та навичок з наступних питань (тем):

- соціологія як наукова дисципліна, передумови іiі виникнення, дисциплінарні кордони, зв'язки та взаємодія з дотичними дисциплінами;

- $\quad$ напрямки та логіка розвитку соціологічних знань, зокрема, орієнтованих на вивчення проблем соціальної сфери, а саме: соціальні нерівності та стратифікація суспільства, феномен влади, аномії, маргінальності, девіантної поведінки тощо;

- $\quad$ зміст, історія виникнення й сучасні тенденції інтерпретації таких понять, як: (1) суспільство, соціальна категорія та група, соціальні зв'язки, стосунки; (2) культура, соціалізація, цінності, норми, значення; (3) соціальна нерівність та стратифікація, соціальна структура, соціальна мобільність; (4) соціальний порядок та контроль, мораль, право, аномія, девіантна поведінка; (5) соціальний інститут (сім'я, освіта, релігія, економіка, політика, медіа); (6) особистість, соціальні ролі та статуси; (7) соціальні зміни.

${ }^{1}$ Формулюється у варіанті, який знаходиться зараз на етапі громадського обговорення та представлений на сайті кафедри соціології управління та соціальної роботи за посиланням https://drive.google.com/file/d/1KHyOEzL5qlXD1YZ1XSq-ggsmwrQITLTT/view

${ }^{2}$ Там саме. 
Переходячи до розкриття реалізації цих завдань в курсах «Історія соціології» та «Соціологія» (саме в такій послідовності вони представлені в актуальному навчальному плані освітньої програми та викладаються у першому та другому семестрі відповідно), назвемо також інші курси, що формують соціологічну складову підготовки соціальних працівників. Серед них: «Методологія і організація соціологічного дослідження», «Методи збору, комп'ютерної обробки та аналізу соціологічних даних», «Якісні методи в соціології», «Соціологія сім’ї», «Девіантологія», «Соціологія управління», «Соціологія культури», «Гендерні дослідження», «Галузеві соціології».

«ІІторія соціології» $є$ дисципліною, що спрямована на ознайомлення студентів із класичною спадщиною соціології з метою орієнтування в особливостях функціонування сучасного стану соціології. Незважаючи на невпинні трансформації суспільства, соціологія раз за разом повертається до осмислення соціальних проблем, що виникли внаслідок ерозії традиції, яка до цього часу інтегрувала суспільство в єдину (словами Е. Дюркгейма «механістичну») систему. Георг Зіммель сформулював базове питання соціології таким чином: «Як можливе суспільство?» [8]. 3 цього питання випливає увага соціологів до (1) порядку, який забезпечується суспільством та не дає йому дезінтегруватися, та до (2) конфліктів, якими супроводжуються будь-які соціальні зміни.

Соціологія розглядає суспільство на соцієтальному рівні культури та політики, мезорівні соціальних інститутів та великих соціальних груп, мікрорівні повсякденної взаємодії. Виходячи з того, що проблеми функціонування суспільства актуалізуються на всіх виокремлених рівнях, нами був підібраний історико-соціологічний матеріал, який дає розуміння того, яким чином та за яких обставин почалося виокремлення та дослідження соціальних проблем, вирішенню яких присвячує свою професійну діяльність соціальний працівник. Отже, ми пропонуємо переорієнтувати увагу студентів освітньої програми «Соціальна робота» 3 методологічних особливостей соціологічного теоретизування (позитивізм, марксизм, розуміюча соціологія тощо) на онтологічні, які допоможуть розкрити зв'язок між особливостями окремих суспільств та концепціями, що були вироблені з метою вирішення актуальних соціальних проблем.

Велика кількість різнорідних теоретико-методологічних напрямів дослідження суспільства породжує необхідність парадигмального об'єднання соціологічних концепцій задля ефективного розуміння студентами сутності соціологічного мислення. На наш погляд, таку теоретичну рамку, яка вичерпно відображає напрямки соціологічного теоретизування, запропонував Р. Коллінз. Вона включає: традицію конфлікту (розкриття змісту феноменів соціальної нерівності, типів стратифікації та влади, переважно на макрорівні суспільства), традицію порядку (у фокусі дослідження знаходиться феномен безконфліктного існування суспільства як цілісної системи), традицію мікроінтеракціонізму (дослідження ведеться у напрямку вивчення безпосередньої взаємодії акторів) та раціонально-утилітарну традицію (дослідницька увага акцентується на зв'язку між інструментальною раціональністю та суспільним добробутом). Базовими критеріями, за якими формується така рамка, стали метапарадигма (соціологічний реалізм або соціологічний номіналізм), у руслі якої сформульована така концепція, та фундаментальний соціальний феномен, з якого, згідно із концепціями, вибудовується соціальна реальність (конфлікт, солідарність, ідентичність або обмін відповідно) [9].

У процесі викладання історико-соціологічного матеріалу окремо зазначається увага на особливостях формування виокремлених традицій у межах різних соціокультурних просторів: такий виклад навчального матеріалу допомагає зрозуміти логіку формування соціологічних наративів, що складаються у рамках відповідних національних соціологічних 
шкіл, які розділені не лише за державними кордонами (які стають більш прозорими протягом просування глобалізації), але й за лінгвістичними особливостями. Так, Й. Галтунг формулює «напівсерйозну» типологію інтелектуальних стилів, які відрізняються не лише мовними особливостями, але й змістовним наповненням [10]. Розуміння інтелектуальних стилів допомагає знайти зв'язок між змістом соціологічних концепцій та практичним значенням для того соціокультурного простору, у межах якого вони сформувалися.

Метою вивчення традиції конфлікту є розуміння механізмів формування соціальних нерівностей між різними соціальними групами, в тому числі професійними. Традиція конфлікту дозволяє навчитись осягати причини, розвиток та потенційні наслідки соціальних конфліктів, винаходити чинники розподілу влади, що сприяє опануванню студентами компетентностей соціального інжинірингу. Це допомагає зрозуміти тенденції динамічного розвитку сучасного ринку праці, який детермінує перманентну необхідність підвищення та/або зміни кваліфікації фахівцями, загрожує зростанням стресовості їхньої професійної діяльності. Інтенсифікація розгалуженості праці актуалізує проблематику відчуження, наслідком якого стає втрата професійної мотивації та, відповідно, - «професійне вигорання». Традиція конфлікту базується на роботах К. Маркса, Ф. Енгельса, М. Вебера та Г. Зіммеля. Розуміння матеріалу передбачає вміння оперувати такими поняттями, як «влада», «соціальний клас», «легітимність» тощо.

Ознайомлення студентів із традицією порядку дозволяє сформувати розуміння закономірностей функціонування суспільства як цілісної системи. Таким чином майбутні соціальні працівники мають змогу дослідити чинники збереження соціального порядку та розвинути компетенції соціального прогнозування, ознайомившись із потенційними наслідками руйнування суспільної солідарності. Ключовими постатями, які розвивають таку проблематику, є О. Конт, Г. Спенсер та Е. Дюркгейм. Вивчення їхніх робіт дозволяє зрозуміти соціологічний зміст понять «система», «структура», «соціальний інститут», «функція», «статус», «солідарність» тощо, які є базовими для цієї традиції.

Мікроінтеракціоністська парадигма акцентує увагу на формуванні знань щодо соціальної реальності, які вибудовуються внаслідок повсякденних інтеракцій. Ця традиція дає змогу визначити витоки формування людської особистості, зрозуміти причини встановлення стосунків між представниками різних культурних форм, сформувати технології інклюзії соціальних груп. Вивчення інтеракціоністської парадигми передбачає ознайомлення 3 роботами Ч. Х. Кулі, Дж.Г. Міда, А. Шюца, I. Гофмана та засвоєння понять «маргінальність», «ідентичність», «соціальна дистанція» тощо.

Раціонально-утилітарна традиція приходить до соціології внаслідок «експансії» економічної науки. Базові поняття, якими оперує ця традиція, досліджують поведінку людей у зв'язку із їхніми раціональними інтересами. Ознайомлення із роботами цього напрямку дає можливість застосовувати інституційний підхід в аналізі людської мотивації та прогнозуванні людської поведінки у контексті раціоналізації сучасного суспільства. Цей напрям теоретизування сформований завдяки роботам Дж. Локка, Дж. С. Мілля, Дж. Хоманса.

Представлені теоретичні напрямки вивчення історії соціології доповнені вивченням генези формування методів соціологічних досліджень у зв'язку з їхнім застосуванням до дослідження соціальних проблем у відповідних соціокультурних умовах, а також шляхів розвитку української соціології у світовому контексті соціологічної думки. Відповідне структурування дисципліни сприяє системному формуванню у студентів категоріального апарату, який готує їх до вивчення соціології та дотичних до неї дисциплін.

За результатами імплементації обраної теоретичної рамки та з огляду на завдання соціологічної складової ОПП «Соціальна робота» до структури дисципліни «Історія 
соціології», що викладається для студентів цієї програми, були включені такі теми: (1) становлення соціології як позитивної науки, (2) соціальні інститути у структурі суспільства, (3) проблематика конфліктів у класичній соціології, (4) влада, нерівності та чинники соціальної стратифікації, (5) внесок психологізму у розвиток соціологічного мислення, (6) феномен маргінальності та розвиток урбаністичної соціології, (7) становлення кількісної та якісної методології дослідження соціальних проблем та (8) вивчення соціальних проблем у фокусі становлення та розвитку української соціології.

Такий аналіз історії соціологічної традиції формує підгрунтя для курсу «Соціологія». Його тематичний план складається 3 чотирьох розділів, які, в свою чергу розкривають наступні соціологічні поняття: (1) Суспільство: соціальна дія, взаємодія, стосунки, групи, організації, соціальна структура, масові та соціальні рухи, соціальні зміни; (2) Культура: соціалізація, особистість, цінності, норми, значення, культурне розмаїття та неоднорідність, культурна ідентичність; (3) Соціальна нерівність: соціальна стратифікація, клас, гендер, етнічність, раса, мобільність, конфлікт, влада; (4) Соціальні інститути: соціальний порядок, соціальний контроль, мораль, право, аномія, девіація, сім'я, освіта, економіка, політика, релігія, соціальна система. Зміст курсу спрямований на засвоєння концептів, вивчення відповідних феноменів на прикладі сучасного, зокрема українського, суспільства, застосування понять для розуміння та пояснення соціального життя, специфічних професійних ситуацій соціальної роботи. Саме таким чином, на нашу думку, відбувається формування соціологічного підгрунтя професійної свідомості майбутніх соціальних працівників.

Наведений вище перелік соціологічних дисциплін у структурі підготовки соціальних працівників є доволі широким, і це знімає необхідність включення в структуру курсу «Соціологія» тем, що стосуються особливостей соціології як науки, методів соціологічних досліджень, аналізу окремих соціальних інститутів, а також огляду витоків та історії соціологічної думки. У цьому, зокрема, полягає відмінність у структурі та формі курсу «Соціологія» для ОПП «Соціальна робота» від аналогічних курсів, що пропонуються іншим непрофільним аудиторіям [11].

Завдання конструювання змістовно насиченого, орієнтованого на практику й ефективного навчального курсу потребує звернення також до психолого-педагогічних та дидактичних аспектів, запровадження відповідної системи методів викладання, навчання, підтримки та оцінювання навчальної діяльності. У цьому контексті ми орієнтуємося на модель емпіричного навчання Д. Колба, яка стала відомою в освіті дорослих $[12,13,14]$ та широко використовується у вищій школі. Вона орієнтує на поєднання у навчальній діяльності методів та прийомів розвитку як пізнавально-когнітивної сфери, емоційно-чуттєвого досвіду, так і різноманітних завдань (вправ, проєктивних ситуацій тощо), наближених до контексту професійної діяльності. Як відомо, цикл емпіричного навчання Д. Колба включає етапи конкретного досвіду, рефлексивного спостереження, абстрактної концептуалізації та активного експериментування.

Вирішення цих завдань на першому курсі навчання в університеті та, відповідно, початкових кроках освоєння майбутньої професії вимагає специфічного навчального середовища. Так, для реалізації етапу конкретного досвіду пропонуємо активне залучення власних спогадів студентів щодо різноманітних соціальних ситуацій (наприклад, встановлення та розриву зв'язків, соціалізації в новому соціокультурному середовищі, існування в рамках соціальних інститутів, отримання нового статусу, участі у конфліктах, сприйняття культурного розмаїття тощо). Іншим важливим джерелом досвіду для нашої аудиторії $є$ популярна культура, зокрема, кінематограф. Створена за участю самих студентів 
колекція фільмів про соціальну роботу ${ }^{3}$ (в них соціальні працівники є героями фільму, мова йде про спричинені соціальною нерівністю проблеми, або героями є представники уразливих груп населення) використовується як матеріал для аналізу, ілюстрації та візуалізації, проєктивних завдань тощо. Також застосування соціологічних концепцій для аналізу культурних продуктів, зокрема кінофільмів, сприяє формуванню соціологічного мислення, яке, за Ч. Р. Міллсом, полягає у вмінні прослідкувати вплив макросоціальних процесів на індивідуальні біографії соціальних акторів [15].

Робота з підручником (окрім вітчизняних використовується підручник 3 соціології Е. Гіденса [16], перекладений українською мовою ${ }^{4}$ ) доповнюється в курсах вивченням першоджерел. Вони дозволяють студентам вступити в безпосередній контакт 3 класиками, відчути їхній специфічний стиль письма, отримати досвід сприйняття розмаїття соціологічного теоретизування, побачити, як конструюються соціологічні поняття, будується академічний текст (перелік матеріалів першоджерел наведений в списку літератури [17-34]). Матеріали першоджерел використовуються для усних та письмових форм роботи, індивідуальних та групових, репродуктивних та творчих.

Методи викладання, які використовуються на курсах «Історія соціології» та «Соціологія», орієнтовані на залучення студентської аудиторії до навчальної діяльності, зокрема в умовах дистанційного навчання. Орієнтуючись на концепцію освітніх завдань «Таксономія Б. Блума» [35], використовуються форми навчальної діяльності для забезпечення інформованості (знання) (зокрема тестові завдання, робота 3 категоріальним апаратом як у форматі індивідуальних завдань, так і в форматі групової роботи), розуміння (різноманітні завдання на перетворення, переказ своїми словами, переведення інформації 3 текстового вигляду у графічний тощо), застосування (завдання на використання понять та концепцій для опису, пояснення та розуміння соціальних явищ та процесів). Освітні завдання вищого рівня - аналіз, синтез, оцінювання - вирішуються у написанні індивідуального науково-дослідного завдання, у ході якого студенти формують навички аналізу та порівняння різних соціологічних парадигм, концепцій, підходів. Загалом, дизайн навчальної активності під час вивчення «Історії соціології» та «Соціології» передбачає застосування активних та інтерактивних методів викладання, зокрема колоквіумів, групових робіт із захистом проєкту, рольових ігор тощо.

Підсумовуючи, зазначимо, що концептуалізація соціологічної складової освітньої програми «Соціальна робота» в рамках курсів «Соціологія» і «Історія соціології» передбачає діяльність на різних рівнях: від визначення мети та завдань цієї складової в системі підготовки соціальних працівників, їх пріоритезації, до вибору форм навчальної діяльності студентів. Важливе місце в цьому процесі належить концептуальній роботі, за допомогою якої завдання професійного становлення соціального працівника знаходять відповідність у соціологічних поняттях та теоріях. Деякі з результатів цієї роботи представлені в статті.

3 Студентки збирають іiі протягом семестру, і вона вже налічує понад 80 фільмів, переважно створених в останні 20 років.

${ }^{4}$ В наступному році очікуємо можливості використання підручника П. Штомпки, який нещодавно був перекладений українською мовою за підтримки Фонду Г. Бьоля. https://ua.boell.org/uk/2021/01/28/sociologiya-analiz-suspilstva 


\section{Література:}

1. Андрющенко А. И. Институционализация социальной работы как науки и профессии в Украине. Социальная работа: история, теория и практика : монография / под ред. В. В. Харабета, Л. М. Хижняк, А. И. Андрющенко. Мариуполь : ПГТУ, 2015. С. 75-89.

2. Горбунова-Рубан С. А. Становление социальной работы в Украине: исторический аспект. Социальная работа: история, теория и практика : монография / под ред. В. В. Харабета, Л. М. Хижняк, А. И. Андрющенко. Мариуполь : ПГТУ, 2015. С. 15-31.

3. Свдокимова I. А. Кафедра соціології управління та соціальної роботи ХНУ ім. В. Н. Каразіна та відділення НСПП в Харківській області: досвід плідної праці. Вдосконалення системи колективно-договірного регулювання як необхідна умова стабільності соиіально-трудових відносин та подальшого розвитку соиіального діалогу в Україні : матеріали наук.-практ. конф., м. Харків, 8 листопада 2018 р. Харків, 2018. С. 49-51.

4. Андрющенко А. І., Горбунова-Рубан С. О. Підготовка соціальних працівників в Україні: проблеми та шляхи їх вирішення. SОСІОПРОСТIP: міждисциилінарний збірник наукових працьь з соціології та соціальної роботи. 2019. № 8. С. 35-40. URL: https://periodicals.karazin.ua/socioprostir/article/view/12776 (дата звернення 30.03.2021).

5. Яковлєв М., Кабаченко Н. Освіта та професійна підготовка соціальних працівників: стислий огляд світової практики. Наукові записки НаУКМА. 2011. Том 123. C. 54-60.

6. Мешкун А. Д., Острянко Т. С. Історичний екскурс становлення соціальної роботи економічно розвинутих країн 3 підготовки соціальних працівників. Проблеми сочіальної роботи: філософія, психологія, сочіологія. 2017. № 1 (9). С. 54-61.

7. Профатилова К. С. Професійна підготовка соціальних працівників у системі вищої освіти України. Вісник Луганського начіонального університету імені Тараса Шевченка. Педагогічні науки. 2014. № 4. С. 134-140.

8. Зиммель Г. Как возможно общество? Социологический журнал. 1994. № 2. C. $102-114$.

9. Коллинз Р. Четыре социологических традиции / пер. с англ. В. Россмана. Москва : Издательский дом «Территория будущого», 2009. 318 с.

10. Galtung J. Struktur, Kultur und intellektueller Stil. Leviathan. 1983. P. 303-338.

11. Сорока Ю. Г. Программа и методические материалы по курсу «Социология» для студентов несоциологических специальностей. Харьков : ХНУ имени В. Н. Каразина. 2003. $21 \mathrm{c}$.

12. Kolb D. A. Experiential learning: Experience as the Source of Learning and Development. Englewood Cliffs, NJ : Prentice-Hall, 1984. 248 p.

13. Дернова М. Моделі емпіричного навчання дорослих: зарубіжний досвід. Порівняльно-педагогічні студії. 2015. № 2. С. 40-45.

14. Ярошинська О., Осадченко Т. Удосконалення підготовки майбутніх учителів до створення здоров'язбережувального середовища початкової школи на основі запровадження моделей емпіричного навчання. HUMANITARIUM. 2015. № 37. С. 170-180.

15. Миллс Ч. Р. Социологическое воображение. Москва : Издательский дом NOTA BENE, 2001. $264 \mathrm{c}$.

16. Гіденс Е. Соціологія / пер. з англ. В. Шовкун, А. Олійник / за ред. О. Іващенко. Київ : Основи, 1999. 726 с.

17. История теоретической социологии. Предыстория социологии : учеб. пособ. 3-е изд, перераб. и доп. / Давыдов Ю. Н. и др. Москва : Академический Проект; Гаудеамус, 2010. $274 \mathrm{c}$. 
18. Шацки Т. История социологической мысли. Том 1. Москва : Новое литературное обозрение, 2018. 720 с.

19. Шацки Т. История социологической мысли. Том 2. Москва : Новое литературное обозрение, 2018. 720 с.

20. Арон Р. Етапи розвитку соціологічної думки / пер. 3 фр. Г. Філіпчука. Київ : Юніверс, 2004. 688 с.

21. Гуменюк Л. Й. Соціологія: Хрестоматія (від першоджерел до сучасності) : навч. посіб. У 2-х томах. Львів : ЛьвДУВС, 2019.

22. Дюркгейм Э. О разделении общественного труда / пер. с фр. А. Б. Гофмана. Москва : Канон, 1996. 432 с.

23. Маркс К. К критике политической экономии. Предисловие / К. Маркс, Ф. Энгельс. Избранные сочинения. Том 7. Москва : Издательство политической литературы, 1987. C. 5-9.

24. Энгельс Ф. Положение рабочего класса в Англии / К. Маркс, Ф. Энгельс. Избранные сочинения. Том 1. Москва : Издательство политической литературы, 1984. С. 223-482.

25. Зиммель Г. Конфликт современной культуры. Избранное. Том 1. Философия культуры. Москва : Юристь, 1996. С. 494-516.

26. Вебер М. Основные социологические понятия. Хозяйство и общество. Очерки понимающей социологии. Том 1. Социология. Москва : Издательский дом Высшей школы экономики, 2016. С. 67-112.

27. Вебер М. Сословия и классы. Хозяйство и общество. Очерки понимающей социологии. Том 1. Социология. Москва : Издательский дом Высшей школы экономики, 2016. C. 334-342.

28. Тард Г. Общественное мнение и толпа. Москва : Ленанд, 2015. 208 с.

29. Гофман И. Моральная карьера душевнобольного пациента (глава из кн. Приюты). Социальные и гуманитарные науки. Сер. 11. Социология. 2001. № 1. С. 105-148.

30. Парк Р. Культурный конфликт и маргинальный человек. Couиальные $u$ гуманитарные науки. Сер. 11. Социология. 1998. № 2. С. 172-175.

31. Франко I. Про працю. Зібрання творів у 50-тm. Київ : Наукова думка, 1984. Том 44. Кн. 1. С. 32-33.

32. Драгоманов М. П. Чудацькі думки про українську національну справу. URL: https://chtyvo.org.ua/authors/Drahomanov_Mykhailo/Chudatski_dumky_pro_ukrainsku_natsionaln u_spravu (дата звернення: 14.03.2021).

33. Бурлачук В. Богдан Кістяківський та його проект створення наукової соціології / під ред. В. Танчера. Біля витоків соціологічної думки в Україні. Київ : Інститут соціології НАН України, 1995. С. 78-101.

34. Рибщун О. Особливості розвитку української соціології за радянських часів. Історія украӥнської сочіологї : навчал. посіб. Київ : Кондор, 2018. С. 281-332.

35. Bloom B. S. Taxonomy of Educational Objectives. URL: https://www.uky.edu/ rsand1/china2018/texts/Bloom\%20et\%20al\%20Taxonomy\%20of\%20Educati onal\%20Objectives.pdf (дата звернення: 07.03.2021).

\section{References:}

1. Andryuschenko, A. I. (2015). Institutialization of Social work as a science and a profession in Ukraine. In V. Kharabet (Ed.), Social work: History, Theory and Practice: monograph (pp. 75-89). Mariupol: PHTU. 
2. Gorbunova-Ruban, S. A. (2015). Formation of Social work in Ukraine: historical aspect. In V. Kharabet (Ed.), Social work: History, Theory and Practice: monograph. Mariupol: PHTU. 15-31

3. Yevdokymova, I. A. Department of Sociology of Management and Social Work, V.N. Karazin National University and the branch of the NSPP in the Kharkiv region: the experience of fruitful work. Improving the system of collective bargaining as a necessary condition for the stability of social and labor relations and further development of social dialogue in Ukraine, Scientific practice conference, November 8, 2018. Kharkiv.

4. Andryuschenko, A. I., \& Gorbunova-Ruban, S. A. (2019). Training of social workers in Ukraine: problems and ways to solve them. SOCIOPROSTIR: the interdisciplinary online collection of scientific works on sociology and social work, 8, 35-40.

5. Yakovliev, M. \& Kabachenko, N. (2011). Educational and vocational training of social workers: an overview of world practices. NaUKMA Research Papers, 123, 54-60.

6. Mekshun, A. D. \& Ostrianko, T. S. (2017). Historical digression of the formation of social work of economically developed countries for the training of social workers. Problems of social work: Philosophy, Psychology, Sociology, 1 (9), 54-61.

7. Profatilova, K. S. (2014). Professional training of social workers in the system of higher education of Ukraine. Bulletin of Luhansk Taras Shevchenko National University. Pedagogical sciences, 4, 134-140.

8. Zymmel, H. (1994). How is society possible? Sociological Journal, 2, 102-114.

9. Kollinz, R. (2009). Four sociological traditions. Moscow: Territory of the Future Publishing House.

10. Galtung, J. (1983). Struktur, Kultur und intellektueller Stil. Leviathan, 303-338.

11. Soroka, Y. G. (2003). Program and teaching materials for the course "Sociology» for students of non-sociological specialties. Kharkiv: V. N. Karazin Kharkiv National University.

12. Kolb, D. A. (1984). Experiential learning: Experience as the Source of Learning and Development. New York, NY: Englewood Cliffs, Prentice-Hall.

13. Dernova, M. (2015). Models of empirical adult learning: foreign experience. Comparative and pedagogical studies, 2, 40-45.

14. Yaroshinska, O. \& Osadchenko, T. (2015). Improving the preparation of future teachers to create a healthy environment for primary school through the introduction of models of empirical learning. HUMANITARIUM, 37, 170-180.

15. Mills, Ch. R. (2001). Sociological imagination. Moscow: NOTA BENE Publishing House.

16. Giddens, E. (1999). Sociology. Kyiv: Osnovy.

17. Davidov, Y. N. (Ed.). (2010). History of theoretical sociology. Prehistory of sociology: A textbook for universities. Moscow: Academic Project, Gaudeamus.

18. Shatsky, Y. (2018). History of sociological thought. Book 1. Moscow: New Literally Digest.

19. Shatsky, Y. (2018). History of sociological thought. Book 2. Moscow: New Literally Digest.

20. Aron, R. (2004). Stages of development of sociological thought. Kyiv: Univers.

21. Humeniuk, L.I. (2019). Sociology: Reader (from primary sources to the present): a textbook. Lviv: LvDUVS.

22. Durkheim, E. (1996). The Division of Labour in Society. Moscow: Canon.

23. Marx K. (1987). A contribution to the Critique of Political Economy. In K. Marx \& F. Engels, Selected works. Book 7. (pp. 5-9). Moscow: Political Literature Publishing House. 
24. Engels F. (1984). The Condition of the Working Class in England. In K. Marx \& F. Engels, Selected works. Book 1. (pp. 223-482). Moscow: Political Literature Publishing House.

25. Simmel, G. (1996). The Conflict of Modern Culture, Selected works. Philosophy of Culture (pp. 494-516). Moscow: Lawyer.

26. Weber, M. (2016). Basic Concepts of Sociology, Economy and Society: An Outline of Interpretive Sociology. Book 1. Sociology. (pp. 67-112). Moscow: Higher School of Economics Publishing House.

27. Weber, M. (2016). Estates and Classes, Economy and Society: An Outline of Interpretive Sociology. Book 1. Sociology. (pp. 334-342). Moscow: Higher School of Economics Publishing House.

28. Tarde, G. (2015). Public Opinion and Crowd. Moscow: Leland.

29. Goffman, E. (2001). The moral career of the mental patient. Social and Humanitarian Sciences. Sociology, 1, 105-148.

30. Park, R. (1998). Cultural Conflict and The Marginal Man. Social and Humanitarian Sciences. Sociology, 2, 172-175.

31. Franko, I. (1984). On the Labour, Collected works in 50 books (pp. 32-33). Kyiv: Scientific Thought.

32. Dragomanov, M. P. (1915). Strange thoughts about the Ukrainian national cause.

Retrieved

from https://chtyvo.org.ua/authors/Drahomanov_Mykhailo/Chudatski_dumky_pro_ukrainsku_natsionaln u_spravu/.

33. Burlachuk, V. (1995). Bohdan Kistiakivsky and his project to create a Scientific Sociology. In V. Tancher (Ed.), The origins of sociological thought in Ukraine (pp. 78-101). Kyiv: National Academy of Sciences of Ukraine. Institute of Sociology.

34. Rybschun, O. (2018). Features of Ukrainian Sociology in Soviet times. In Burlachuk V. et al, History of Ukrainian Sociology (pp. 281-332). Kyiv: Kondor.

35. Bloom, B. S. Taxonomy of Educational Objectives. Retrieved from https://www.uky.edu/ rsand1/china2018/texts/Bloom\%20et\%20al\%20Taxonomy\%20of\%20Educati onal\%20Objectives.pdf. 